\title{
Effect of Audit Quality on the Financial Performance of Selected Banks in Nigeria
}

\author{
Ogbodo, Okenwa Cy, Akabuogu, Nzube J. \\ Department of Accountancy, \\ Nnamdi Azikiwe University, Awka, Nigeria
}

\section{ABSTRACT}

This study which focused on the "the effect of audit quality on the corporate performance of selected banks in Nigeria" was prompted as a result of inability of audit to prevent the occurrence of fraud and material misstatement in the bank's financial reports. Thus, this study is aimed at assessing the effect of audit quality on the corporate performance of selected banks in Nigeria. Specifically, the study examined the effect of audit firm size on return on asset of Nigerian banks; determined the extent audit committee independence affect return on equity of Nigerian banks and ascertained the effect of audit committee on the profit margin of Nigerian banks. Three research questions and hypotheses were formulated in line with the objectives of this study. The population of the study consists of sixteen deposit money banks quoted on the Nigerian Stock Exchange. Data for the study were extracted through the financial statement of the banks from 2008 to 2017 and was tested with regression statistical tool using the Scientific Package for Social Sciences (SPSS) Version 20. Based on the data analyzed, the study found that firm size has significant effects on return on assets of quoted Nigerian banks; also that audit committee independent has significant affect return on equity of quoted Nigerian banks. Another finding is that audit committee size has significantly affects profit margin of quoted Nigerian banks. Based on this, the study recommended among others that companies should make use of the services of audit firms with unquestionable track records of audit quality and reputation; hence the debate on audit quality is not a settled matter.

KEY WORDS: Audit Quality, Financial Performance and Deposit Money banks

\section{INTRODUCTION}

The Audit quality can be defined in two dimensions: first, detecting misstatements and errors in financial statement and second, reporting these material misstatements and errors (Matoke \& Omwenga, 2016). Due to the fact that these characteristics are largely unobservable, different proxies have been used by researchers like; Bogale (2016); Hassan (2015); Yi-Fang, Lee-Wen, and Min-Ning (2015) to measure audit quality like: audit size, audit hours, audit fees, reputation, litigation rate and discretionary accruals (Krishnan \& Schauer, 2000).

Audit quality is subject to many direct and indirect influences. In tandem with the stakeholder theory (Khan, 2006), perceptions of audit quality vary amongst stakeholders depending on their level of direct involvement in audits and on the perspective through which they assess audit quality. In recent times, a series of well-publicized cases of accounting improprieties in Nigeria has captured the attention of investors and regulators alike. The search for mechanisms to ensure reliable, high quality financial reporting has largely focused on the structure of audit quality (Adeyemi \& Fagbemi, 2010).

The spate of audit failures in the world has brought a great deal of disappointment to investors and other corporate financial reporting stakeholders. Longevity of audit firm tenure has also been linked with fraudulent financial reporting (Adeyemi, Okpala \& Dabor, 2012). If empirical studies are not carried out with respect to specific environmental factors the problem of poor audit quality may be exacerbated with likely grave consequences for the selected banks. Although, various researchers have carried out study on this area such as the following: Adeyemi and Fagbemi, (2010) Audit quality, corporate governance 
and firm characteristics in Nigeria; Musa \& Shehu, (2014) in his study investigates the impact of audit quality on financial performance of quoted firms in Nigeria. Gholamreza \& Samira, (2015) the relationship between auditing quality and the profitability in the companies accepted in Tehran's securities exchange market; Matoke and Omwenga, (2016) Audit quality and financial performance of companies listed in Nairobi Securities; Amahalu and Ezechukwu, (2017) ascertain the determinants of audit quality with a focus on selected Deposit Money Banks listed on the floor of Nigeria Stock Exchange from 2010-2015; Egbunike and Abiahu (2017) The effect of audit firm characteristics on financial performance of money deposit banks in Nigeria.

However, despite all these studies on audit quality, a gap exists in the literature pertaining to the audit quality and financial performance, the study discovered from the ongoing review of previous researchers, that majority of the studies were done outside Nigeria, there exist location gap. Besides, these studies used different methods and design like survey research design which employed the use of questionnaire but the researcher adopted ex-post facto which employed the use of secondary data and reports from financial statements, there exist methodology gap. It is for this reasons that the researcher set up to investigate the effect of audit quality on the corporate performance of selected banks in Nigeria.

Owing to the problem of the study, the main objective of this study is aimed at assessing the effect of audit quality on the corporate performance of selected banks in Nigeria.

Therefore the following specific objectives are set out below:

1. To examine the effect of audit firm size on return on equity of Nigerian banks.

2. To determine whether audit committee independence affect return on equity of Nigerian banks.

3. To ascertain the effect of audit committee on the profit margin of Nigerian banks.

\section{CONCEPTUAL REVIEW}

\subsubsection{Audit Quality}

The various changes in accounting, financial reporting and auditing were all designed to provide protection to investors. This is being achieved by imposing a duty of accountability upon the managers of a company (Crowther \& Jatana, 2005). More precisely, the role of auditing is to reduce information asymmetry on accounting numbers, and to minimize the residual loss resulting from managers' opportunism in financial reporting. Effective and perceived qualities (usually designated as apparent quality) are necessary for auditing to produce beneficial effects as a monitoring device. The perceived audit quality by financial statements users is at least as important as the effective audit quality. Conceptually, Agency theory recognizes auditing as one of the main monitoring mechanisms to regulate conflicts of interest and cut agency costs (Adeyemi \& Fagbemi, 2010).

According to DeAngelo (1981), audit quality is defined as the competency and independence of auditors in detecting and reporting material misstatement. Zehri and Shabou (2011) asserted that high quality auditors are more likely to discover questionable accounting practices by clients and report material irregularities and misstatements compared with low quality auditors. Due to this, a higher audit quality is able to better constrain earnings management, and in turn enhance the quality of financial reports (Ching, Teh, San \& Hoe, 2015). Previous research in the related literature has employed various measures as proxies of audit quality. Several studies have indicated that a higher quality of auditing mitigates accruals based earnings management (Okolie, 2014; Soliman and Ragab, 2014; Gerayli, Yanesari and Ma'atoofi, 2011; Becker, DeFond, Jiambalvo, \& Subramanyam, 1998). This study used audit firm size, audit fees, and audit partner as audit quality measures.

Conceptually, the auditing quality can be measured through the three basic aspects of inputs, outputs and environmental factors. Except auditing standards, there are other inputs for the auditing quality. One such an input is the unique and prominent features of the auditor such as his or her experience, moral values and his propensities. One of the other important factors is the auditing process (Rahimi \& Amini, 2015). This process includes auditing methodology, the amount of the effects of the applied auditing methods and the amount of access to the required auditing documents and evidences.

\section{Composition of the Audit Committee}

Based on the Audit Committee, on the one hand internal auditing contribute to corporate governance 
by: Bringing best practice ideas about internal controls and risk management processes to the audit committee; providing information about any fraudulent activities or irregularities; conducting annual audits and reporting the results to the audit committee; encouraging audit committee to conduct periodic reviews of its activities and practices compared with current best practices to ensure that its activities are constituent with leading practices (Ejeagbasi, Nweze, Ezeh, \& Nze, 2015). From the other hand, effective audit committees strengthen the position of the internal audit function by providing an independent and supportive environment and review the effectiveness of the internal audit function (Theofanis, George, Evaggelos \& Ioannis, 2010). The code provided for an audit committee that is expected to be effective and efficient. As such the composition of the audit committee is a dichotomous variable, assigned 1 if there are at least three non - executive directors on the audit committee, otherwise.

\section{Audit Committee Size}

Limited research has been undertaken to investigate the relationship between firm performance and the features of audit committee. Forker (1992) was the first paper to propose this relationship. The author suggests that the audit committee is as an effective monitoring mechanism to enhance the quality of corporate disclosure and reduce agency costs. Furthermore, Ho and Wong (2001) argue that the existence of an audit committee significantly influences the amount of corporate disclosure. In others empirical studies (Barakoet, 2006) conclude the predictable positive connection between audit committee size and level of voluntary disclosure.

\section{Corporate Performance}

There are a few studies that demonstrate that audit quality improves the financial performance of a company. Afza and Nasir (2014) mentioned that quality of external audit improves a firm's performance due to the perception of investors. They perceive that companies that are audited by big audit firms will disclose reliable, proper, and authentic financial reports, which strengthen the overall investors' confidence towards these companies. Furthermore, Jusoh, Ahmad and Omar (2013) claimed that high audit quality might reduce agency costs where auditors provide an indicator about credibility and integrity of financial reports, which could in turn lead to lower monitoring costs and result in better performance by the corporation. Similarly, Fooladi and Shukor (2012), and Farouk and Hassan (2014), reported a significant and positive relationship among audit quality and company performance. Hence, audit quality is expected to have a positive relationship with financial performance.

\section{Return on Capital Employed}

Return on Capital Employed ("ROCE") is a measure of business effectiveness and capital efficiency. ROCE is a function of profitability, how much profit a business generates before interest on debt and tax ( EBIT) and activity, how much a business has invested in operating assets to generate that level of profitability(Wallace, 2012). In the 1920's Du Pont Corporation developed what is commonly known as Du Pont accounting and ROCE as a measure of business performance to enable it to compare the performance of its many different business units. The Du Pont accounting method is a powerful and relatively simple approach to determine the impact of management decisions on financial performance. The advantage of this method is that it provides a consistent form of evaluation for a business to use when measuring performance. At an individual business level ROCE: - allows comparison between business units of different size over time; - shows where to invest further and where to cut back; shows whether it is worth borrowing further to invest; - shows if expectations of shareholders are being met; - indicates the maximum sustainable growth of a business; and - is used to track whether or not a project is performing according to plan(Wallace, 2012). ROCE can be used to test operational efficiency, balance sheet management efficiency and the adequacy of return on total capital employed to make an assessment of a business's performance. ROCE can be used to help management improve both the profitability (EBIT) and balance sheet management. Improvements in these areas will lead to improvements in the Return on Capital employed.

Return on Capital Employed and Return on Equity are so interlinked that both these terms will be considered. These Returns are, basically, simple and useful concepts; they have however been so manipulated (abused, some people would say) over the past few decades that they now more often confuse rather than illuminate the evaluation of company performance (Shoesmith, 2004). The concept of the Returns is intuitively valid and useful: what Return is being made on Capital Employed and on Equity? In particular it is important to know 
whether the company is earning more than its cost of capital. Simplistically, the Return on Capital Employed is the profit before interest and taxation (ie turnover less costs) as a percentage of the capital employed in the business (ie fixed assets and net current assets) irrespective of whether financed by shareholders equity or borrowings (Jim Shoesmith, 2004). It is a measure of the profit earned by the business irrespective of how that business is financed. Also simplistically, the Return on Equity is the profit after interest but before taxation (ie turnover less costs and less interest paid) as a percentage of shareholders equity (capital employed less borrowings). It therefore only differs from Return on Capital Employed as it takes account of the gearing achieved by borrowing.

\section{Return on Assets (ROA)}

Return on assets (ROA) is an indicator of how profitable a company is relative to its total assets. ROA gives a manager, investor, or analyst an idea as to how efficient a company's management is at using its assets to generate earnings (Gallo, 2016).Some investors add interest expense back into net income when performing this calculation because they'd like to use operating returns before cost of borrowing. ROA tells what earnings were generated from invested capital (assets). ROA for public companies can vary substantially and will be highly dependent on the industry. This is why when using ROA as a comparative measure, it is best to compare it against a company's previous ROA numbers or against a similar company's ROA. Remember that a company's total assets are the sum of its total liabilities and shareholder's equity. Both of these types of financing are used to fund the operations of the company. Since a company's assets are either funded by debt or equity, some analysts and investors disregard the cost of acquiring the asset by adding back interest expense in the formula for ROA. In other words, the impact of taking more debt is negated by adding back the cost of borrowing to the net income, and using the average assets in a given period as the denominator. Interest expense is added because the net income amount on the income statement excludes interest expense. An analyst that chooses to ignore the cost of debt will use this formula:

$$
\begin{gathered}
\mathrm{ROA}=(\text { Net Income }+ \text { Interest Expense }) / \text { Average } \\
\text { Total Assets }
\end{gathered}
$$

The ROA figure gives investors an idea of how effective the company is in converting the money it invests into net income. The higher the ROA number, the better, because the company is earning more money on less investment. Let's evaluate the ROA for three companies in the retail industry (Macy, Penney \& Sears, 2017). ROA is most useful for comparing companies in the same industry, as different industries use assets differently. For example, the ROA for service-oriented firms, such as banks, will be significantly higher than the ROA for capital intensive companies, such as construction or utility companies. "ROA simply shows how effective your company is at using those assets to generate profit." This ratio is more useful in some industries than in others, partly because how much money your business has tied up in assets will depend on your industry.

\section{Return on equity (ROE)}

Return on equity (ROE), is a financial ratio that measures the return generated on stockholders'/shareholders' equity, the book or accounting value of stockholders'/shareholders' equity which reflects the accumulation over time of amounts received by the company from stock/share issues plus the profits/earnings retained by the company, i.e., not yet distributed in dividends (accounting value of shareholders' equity is also equal to a company's net assets, i.e., assets minus liabilities).

Furthermore, the ROE can be decomposed to understand the fundamental drivers of value creation in a company. This is known as the DuPont decomposition and can be calculated as:

$\mathrm{ROE}=$ profit margin $\mathrm{X}$ asset turnover $\mathrm{X}$ gearing. $\mathrm{ROE}=$ (profit for the year $\div$ sales) $\mathrm{X}$ (sales $\div$ assets) $\mathrm{X}$ (assets $\div$ shareholders' equity).

\section{Profit Margin}

The profit margin, asset turnover and gearing ratios can further be decomposed to complete the financial statement analysis or ratio analysis of a company. The profit margin tells us how much profit a company makes on every dollar of sales. The asset turnover indicates how efficient a company is in using its assets and reflects how many dollars of sales a company generates from every pound/dollar of assets in the company.

\section{Empirical Review}

Shafie Hussin Yusof and Hussain (2009) examined the relationship between audit firm tenure and auditor reporting quality in Malaysia. This study employs 
well-established going concern model of logistic regression. Their findings show that audit firm tenure is positively significant relationship with auditor reporting quality. Adeyemi and Fagbemi, (2010) state the audit quality, corporate governance and firm characteristics in Nigeria. Therefore, this study provides evidence on corporate governance, audit quality, and firm related attributes from a developing country, Nigeria. Logistic regression was used in investigating the questions that were raised in the study. Findings from the study show that ownership by non-executive director has the possibility of increasing the quality of auditing. Evidence also exist that size of the company and business leverage are important factors in audit quality for companies quoted on the Nigerian Stock Exchange. Zahid, Haider and Asif (2010) investigated the impact of prior year firm's performance on subsequent year firm's corporate governance mechanism. They used board size, CEO-Chairman combined structure and audit expenditure as a firm level corporate governance mechanism. The panel data of fifty two companies listed on Karachi Stock Exchange covering the period from 2006 to 2010 was used for this study. Hypotheses were tested by using fixed effect model and random effect model. Their results revealed that prior year firm's performance has positive relationship with board size but negative relationship with audit expenditure. Umaru, (2011) in his study examined which the impact of audit firms ${ }^{\text {ee }}$ attributes on financial reporting quality of quoted building material firms in Nigeria. The study employed correlation research design using a sample of four listed building material firms for the period of ten years (2002-2011). Ordinary Least Square (OLS) multiple regression technique was employed in the analysis of the panel data collected for the study. The study found that audit compensation and audit firm independence have significant positive impact on the financial reporting quality of quoted building material firms in Nigeria at $99 \%$ confidence level. Adeyemi, Okpala and Dabor, (2012) investigated the factors affecting audit quality in Nigeria. This research was carried out in order to investigate the factors affecting audit quality in Nigeria. The primary data were supplied by 430 respondents across several stakeholders in the fields of financial reporting and auditing. The secondary data were generated from the financial statements of forty annual reports of companies quoted on the Nigerian Stock Exchange. The test of hypotheses and other analysis of data were done using SPSS, version 17. The tests revealed that among others, multiple directorship is the most significant in affecting audit quality in Nigeria. In addition, it is found that provision of non-audit service would likely have a significant effect on the audit quality in Nigeria. Ondieki, (2012) in his study examined effect of internal audit on financial performance in commercial banks in Kenya. Internal audit was looked at from the perspective of internal audit standards, professional competency, internal controls and independence of internal audit. The study selected one senior manager in the finance department. Muazu, (2012) assesses the role of internal auditors in ensuring effective financial control at local government level, a case of Alkaleri L.G.A Bauchi State. The methodology employed for data collection is only primary source, which involved the use of questionnaires, in which 50 questionnaire were administered to the staff of Accounting and Internal audit department of Alkaleri L.G.A, out of which only 35 questionnaires were completed and returned. The data generated for the study were interpreted using simple percentage. The main finding of the study include among other; lack of proper independent exercise by the internal auditor, understaffing in the side of internal audit unit, the internal control system is very weak toward financial and other controls and also non adherence by the auditors on general auditing standard. Ondieki, (2013) also determined the effect of internal audit on financial performance in commercial banks in Kenya. Internal audit was looked at from the perspective of internal audit standards, professional competency, internal controls and independence of internal audit. The study selected one senior manager in the finance department. The researcher administered a survey questionnaire to each member of the target population since it was the most appropriate tool to gather information. Quantitative analysis and regression analysis were used as data analysis technique. From the findings, the study concludes that internal audit standards, independence of internal audit, professional competency and internal control had a positive relationship with financial performance of commercial banks, the study found that a unit increase in internal audit standards would lead to increase in financial performance of commercial banks, a unit increase in independence of internal audit would lead to increase in financial performance of commercial banks, a unit increase in professional competency would lead to increase in financial performance of commercial banks and further unit increase in internal control would lead to increase in financial 
performance of commercial banks. The study recommends that management in commercial banks in Kenya should adopt effective internal audit practices such as internal auditing standards, independence of internal audit, professional competency and internal controls to enhance financial performance of the banks.

Further study by Yahn-Shir, Hsu, Mei-Ting and PingSen, (2013) it was observed that this study examines the relations between audit quality, audit firm size, and financial performance. This study estimates audit quality of audit firms from human capital-related factors, such as educational level of auditors, work experience of auditors, and professional training. From the perspective of market segmentation, the sample is divided into three categories: national, regional, and local firms. Empirical results report a positive association between audit firm size and audit quality for the three categories of audit firms. Mohd, TanjongMalim, AyoibChe and Baharudin, (2013) examined the managerial ownership, audit quality and firm performance in Malaysian. This study investigates the relationship between managerial ownership and company performance of public listed companies in Malaysia. Further, this estudy investigates the effect of audit quality on company performance. As multivariate regression is used to analyze the data in this study, assumptions of multicollinearity, hemoscedasticity and linearity are also tested. Furthermore, this study applied the F-test, Chow test and Hausman test to determine the best statistical method. The analysis utilizing GLS fix effects estimations technique is applied. The results showed that the managerial ownership had negative and significant relationship with ROA and Tobin's Q.

Farouk and Hassan, (2014) opined the impact of audit quality and financial performance of quoted cement firms in Nigeria. This research work was designed to examine the impact of audit quality on financial performance of quoted cement firms in Nigeria. The study is descriptive in nature and the correlational and ex-post facto designs were adopted in carrying out this research. Data were obtained basically from the published annual reports and accounts, and notes to the financial statements of the four firms that represent the sample of the study. The data collected were quantified and presented in tables. Multiple regression analysis was employed in analyzing the data and testing the stated hypotheses. The results of the findings shows that auditor size and auditor independence have significant impacts on the financial performance of quoted cement firms in Nigeria. Morteza, (2014) investigated that audit opinion shopping has been studied extensively in accounting research. A firm engages in opinion shopping by influencing or even manipulating its auditor's decision in certain ways to obtain an opinion that is more favorable that that warranted by the quality of its accounting information.

Musa and Shehu (2014) in their research reveal that the financial statement audit is an important tool for reducing information asymmetries and maintaining an efficient market environment. The study is descriptive in nature and the co relational and ex-post facto designs were adopted in carrying out this research. Data were obtained basically from the published annual reports and accounts, and notes to the financial statements of the four firms that represent the sample of the study. The data collected were quantified and presented in tables. Multiple regression analysis using the SPSS Version 15.0 was employed in analyzing the data and testing the stated hypotheses. The results of the findings shows that auditor size and auditor independence have significant impacts on the financial performance of quoted cement firms in Nigeria. However, auditor independence has more influence than auditor size on financial performance.

Dangana, (2014) examined the impact of audit firms ${ }^{\text {ee }}$ attributes on financial reporting quality of quoted building material firms in Nigeria. The study employed correlation research design using a sample of four listed building material firms for the period of ten years (2002-2011). Ordinary Least Square (OLS) multiple regression technique was employed in the analysis of the panel data collected for the study. The study found that audit compensation and audit firm independence have significant positive impact on the financial reporting quality of quoted building material firms in Nigeria at $99 \%$ confidence level. The finding suggested that, audit compensation and provision of non-audit services in the quoted building material firms in Nigeria have improved the quality of their financial reporting during the period under review. Gholamreza and Samira (2015) who studied the present study deals with the evaluation of the relationship between auditing quality and the profitability in the companies accepted in Tehran's securities exchange market. The total number of 52 companies accepted in Tehran's securities exchange market has been surveyed. The study findings show 
that generally there is a positive and weak relationship between the auditor size (auditor's good fame) and the auditor's tenure period and the profitability ratios. To survey the auditor's size the member auditing institutions of the formal accountant society are regarded as small auditing firms and accounting organization due to the great many staff members working in it and also due to their long working history is considered as the big auditing institution. Also, there is a positive but non-significant relationship between profitability and auditors size and there is a positive and significant relationship between tenure period and profitability. Hamed, Rohaida, Siti and Abdul, (2015) examined the impact of audit quality on firm performance for Malaysian listed companies for the period of 2003 to 2012. In this study, we use audit fees and audit firm rotation as proxies for audit quality. Return on assets and Tobin's q are used as measures for firm performance. Hamed, Rohaida, Siti and Mohamed, (2016) examined the impact of audit quality on firm performance for Malaysian listed companies for the period of 2003 to 2012. In this study, they use audit fees and audit firm rotation as proxies for audit quality. Return on assets and Tobin's q are used as measures for firm performance. They found that there is insignificant relationship between audit quality proxies (audit fees and audit firm rotation) and ROA. They also found that an audit fee is significantly and positively related to Tobin's Q. However, audit firm rotation is insignificantly related to Tobin's Q.

Matoke and Omwenga, (2016) conducted a research work on audit quality and financial performance of companies listed in Nairobi Securities Exchange. This study adopted a descriptive research design. The study used Cronbach (Alpha $-\alpha$ ) model to test the reliability of the data. Quantitative and qualitative data that was collected using questionnaires was inspected for errors and gaps. The data was then well examined and checked for completeness and comprehensibility. After inspection, the data was coded and analyzed by the use of descriptive statistics using SPSS. Data was analyzed by multiple linear regression analysis. Findings of the study indicate that the effect of audit quality on financial performance is positive and significant and the greater the degree of an auditors independence, the greater the propensity of a firm making substantial net profit margins. The impact of auditor size was also positive and significant, although, its impact was lesser that of auditor independence.
Stakebrand, (2016) examined the effects of auditor rotation on audit quality, by focusing on European companies for the period 1995-2014. Similar studies focusing on European companies are rare. Based on prior studies it is hypothesized that audit quality will decrease on the short term after rotation, but will increase on the long term. Also a differential effect between voluntary and mandatory rotation is hypothesized. Three different measures of audit quality are used; discretionary accruals, abnormal working capital accruals, and the ratio of loss avoidance. The results are mixed as dependent on the measure of audit quality there is supporting or contradicting evidence.

Zayol, Kukeng and Iortule (2017) opined the effect of auditor independence on audit quality: a review of literature. This paper reviews literature related to auditor independence and audit quality in order to determine the effect of the former on the latter. The ex post facto research design is employed. Information for this study was obtained from secondary sources to include journals, text books and other internet materials. Based on the review, findings show that there is a strong relationship between auditor independence and audit quality. The review also revealed four threats to auditor independence, which are client importance, non-audit services (NAS), audit tenure, and client's affiliation with CPA firms. However, some studies indicated a positive relationship while others showed contrary due to the type of study design employed, sample size, data collection instruments and analysis techniques used. Most of the studies on auditor independence and audit quality were centered on one or two of the threats and majorly done outside Nigeria.

According to Zayol, Kukeng and Iortule, (2017) they investigated the auditor independence and audit quality are two concepts that work inseparably. Many have argued that auditor independence begets audit quality and as such audit quality cannot be different from the system that produces it. This paper reviews literature related to auditor independence and audit quality in order to determine the effect of the former on the latter. The ex post facto research design is employed. Information for this study was obtained from secondary sources to include journals, text books and other internet materials. Based on the review, findings show that there is a strong relationship between auditor independence and audit quality. The review also revealed four threats to auditor 
independence, which are client importance, non-audit services (NAS), audit tenure, and client's affiliation with CPA firms.

Although, various researchers have carried out study on this area such as the following: Adeyemi and Fagbemi, (2010) Audit quality, corporate governance and firm characteristics in Nigeria; Adeyemi, Okpala and Dabor, (2012) investigated Factors Affecting Audit Quality in Nigeria; Mohd, TanjongMalim, AyoibChe and Baharudin, (2013)examined the The managerial ownership, audit quality and firm performance in Malaysian; Beisland, Mersland and Strøm, (2013)study the audit quality and corporate governance: evidence from the microfinance industry.

Farouk and Hassan, (2014) assessed the impact of audit quality and financial performance of quoted firms in Nigeria. Musa \& Shehu, (2014) in his study investigates the impact of audit quality on financial performance of quoted firms in Nigeria. Gholamreza \& Samira, (2015) the relationship between auditing quality and the profitability in the companies accepted in Tehran's securities exchange market; Matoke and Omwenga, (2016) Audit quality and financial performance of companies listed in Nairobi Securities; Amahalu and Ezechukwu, (2017) ascertain the determinants of audit quality with a focus on selected Deposit Money Banks listed on the floor of Nigeria Stock Exchange from 2010-2015; Egbunike and Abiahu (2017) The effect of audit firm characteristics on financial performance of money deposit banks in Nigeria.

However, despite all these studies on audit quality, a gap exists in the literature pertaining to the audit quality and firm performance, As we can discover from the ongoing review of previous researchers, that some of the study were done outside Nigeria, there exist location gap, some were done using different variable as proxy for performance and audit quality such as return on asset, profit margin, audit fee, audit rotation respectively, there exist variable gap from this study. Some of the researchers used different methods and design like survey research design which employed the use of questionnaire but the researcher adopted ex-post facto which employed the use of secondary data and reports from financial statements, there exist methodology gap.

Therefore, this study focused on audit quality and financial performance of universal banks in Nigeria since none of the study was done on this area in Nigeria. This study therefore fills the research gap by assessing the effect audit quality and financial performance of universal banks in Nigeria using return on asset, profit margin, return on equity and return on capital employed as a variable for performance.

\section{RESEARCH METHODOLOGY \\ Research Design}

This research work adopted an ex-post facto research design. This is because it seeks to establish cause-effect relationship and the researcher has no control over the variable under study.

\section{Sample Size and Sampling technique}

The population size will serve as the sample size since the population size is small. The researcher decides to analyze all the population size since the population size is manageable. Below is the list of selected banks; Access Bank, Diamond Bank, Eco Bank, Fidelity Bank Nigeria, First Bank Nigeria, First city monument Bank, Guaranty Trust Bank, Skye Bank, Stanbic IBTC Bank Nigeria Limited, Standard Chartered Bank, Sterling Bank, Union Bank on Nigeria, United Bank for Africa, Unity Bank PLC, Wema Bank and Zenith Bank plc.

\section{Method of Data Analysis}

For the purpose of empirical analysis the study used regression statistical tool as the underlying statistical tests using Statistical Package for Social Science (SPSS) version 20. The regression analysis is performed on the dependent (Corporate performance) and independent variables (Audit Quality).

\section{Decision Rule}

The decision was based on 5\% level of significance. Accept null hypothesis (Ho) if probability value (i.e. P-value or Sig.) calculated is greater than or equals to $(>)$ stated $5 \%$ level of significance $(\alpha)$; otherwise, reject and accept alternate hypothesis $\left(\mathrm{H}_{\mathbf{a}}\right)$, if $\mathrm{P}$-value or sig calculated is less than $5 \%$ level of significance.

\section{Model Specification and Variable Measurement}

The study considered corporate performance as the dependent variable (ROA,) while Audit Quality 
variables are used as control variables represent independent variables. Each individual performance variables are regressed against the control variables.

The functional form of the model is as follows:

Financial performance $(\mathrm{cp})=\mathrm{f}$ (Audit Quality-

$\mathrm{AQ})$.

Introduced the measured / observed variables $\mathrm{FP}_{\mathrm{it}}-\mathrm{ROA}=\mathrm{F}$ (AQ- audit firm size, audit committee size and

Audit committee independent).

$\mathrm{ROA}_{i \mathrm{t}}=\mathrm{F}\left(\right.$ Audit firm size $\left.-\mathrm{AFS}_{\mathrm{it}}\right)$

Equation iii to $\mathrm{v}$ is functional form or notational model

$\mathrm{ROE}_{\mathrm{it}}=\beta 0+\beta_{1} \mathrm{ACI}_{\mathrm{it}}$
Introduce the error term or stochastic random variable vi-viii deterministic models

$\mathrm{PM}_{\mathrm{it}}=\beta_{0}+\beta_{1} \mathrm{ACZ}_{\mathrm{it}}+\mathrm{E}_{\mathrm{it}}$

is called linear regression $\backslash$ econometric models

Where:

ROA = Return on Assets

ROE = Return on Equity

$\mathrm{PM}=$ Profit Margin

$\mathrm{B}_{\mathrm{O}}=$ Intercept coefficient

$\mathrm{B}_{1}=$ Coefficient for each of the independent Variables

$\mathrm{AQ}=$ Audit quality

$\mathrm{AFZ}=$ Audit Firm Size

$\mathrm{ACZ}=$ Audit committee size

$\mathrm{ACI}=$ Audit committee independent

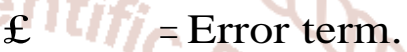

\section{Variable Measurement}

\begin{tabular}{|l|l|l|}
\hline \multicolumn{1}{|c|}{ Variables } & \multicolumn{1}{|c|}{ Measurements } & \multicolumn{1}{c|}{ Type of Variable } \\
\hline ROA & Net Profit/ Total Asset & Dependent Variable \\
\hline ROE & Profit b/f tax/ Total Equity & Dependent Variable \\
\hline Profit margin & Profit b/f tax/ Turnover & Dependent Variable \\
\hline Audit committee size & number of members in the audit committee & Independent Variable \\
\hline $\begin{array}{l}\text { Audit committee } \\
\text { independent }\end{array}$ & using the proportion of non-directors on the board & Independent Variable \\
\hline Audit Firm Size & Big 4=1 none =0 24:56-64:70 & Independent Variable \\
\hline
\end{tabular}

\section{Data analysis}

Table 1: Descriptive Statistics

\begin{tabular}{|c|c|c|c|c|c|}
\hline & $\mathbf{N}$ & Minimum & Maximum & Mean & Std. Deviation \\
\hline ACS & 164 & -1.92 & 7.00 & 5.6937 & 1.10292 \\
\hline AFS & 159 & .00 & 1.00 & .6855 & .46577 \\
\hline ACI & 160 & .00 & 11.00 & 5.5000 & 3.06122 \\
\hline ROA & 160 & -.06 & .41 & .0244 & .04323 \\
\hline ROE & 158 & -3.87 & 1.32 & .0781 & .40585 \\
\hline PM & 158 & -4.44 & 1.44 & .1825 & .44014 \\
\hline Valid N (list wise) & 157 & & & & \\
\hline
\end{tabular}

Table 1 shows the mean (average) for each of the variables, their maximum values, minimum values, and standard deviation. The results in table 1 provide insight in the nature of the Nigerian quoted deposit money banks that were used in this study. It was observed that on the average over the Ten (10) years periods (2008-2017), the sampled quoted Nigerian quoted deposit money banks were characterized by improved financial performance; return on assert $(\mathrm{ROA})=.0244$, return on equity $(\mathrm{ROE})=.0781$ and profit margin $=0.1825$. The gap between the maximum and minimum value of the financial performance and audit quality (audit committee size, audit committee independence, and firm size) shows that audit quality really determine the level of financial performance of the banks. 


\section{Test of Hypotheses}

\section{Hypothesis One}

Ho: There is no significant effect of audit firm size on return on asset of Nigerian banks.

Table 2: Model Summary

\begin{tabular}{|c|c|c|c|c|}
\hline Model & $\mathbf{R}$ & $\mathbf{R}$ Square & Adjusted R Square & Std. Error of the Estimate \\
\hline 1 & $.170^{\mathrm{a}}$ & 0.29 & .023 & .04206 \\
\hline \multicolumn{5}{|c|}{ a. Predictors: (Constant), AFS } \\
\hline
\end{tabular}

Table 3: ANOVA ${ }^{\mathrm{a}}$

\begin{tabular}{|c|c|c|c|c|c|}
\hline Model & Sum of Squares & Df & Mean Square & F & Sig. \\
\hline Regression & .008 & 1 & .008 & 4.675 & $.32^{\mathrm{b}}$ \\
Residual Total & .278 & 157 & .002 & & \\
& .286 & 158 & & & \\
\hline
\end{tabular}

a. Dependent Variable: ROA

b. Predictors: (Constant), AFS

Table 4: Coefficients ${ }^{\mathrm{a}}$

\begin{tabular}{|c|c|c|c|c|c|}
\hline \multirow{2}{*}{ Model } & \multicolumn{2}{|c|}{$\begin{array}{c}\text { Unstandardized } \\
\text { Coefficients }\end{array}$} & $\begin{array}{c}\text { Standardized } \\
\text { Coefficients }\end{array}$ & \multirow{2}{*}{$\mathrm{t}$} & \multirow{2}{*}{ Sig. } \\
\cline { 2 - 4 } & $\mathrm{B}$ & Std. Error & Beta & & \\
\hline (Constant) & .013 & .006 & & 2.202 & .029 \\
AFS & .016 & .007 & .016 & 2.162 & .032 \\
\hline
\end{tabular}

a. Dependent Variable: ROA

Table 2 above shows that the Model revealed the In table 4, the regressed coefficient correlation result value of $\mathrm{R}^{2}=0.029$ and Adjusted $\mathrm{R}^{2}$ value is .023 this $/$ shows that an evaluation of the financial performance suggests that the model explains about $3 \%$ of the systematic variations in the dependent variable. This means that the regression explains $3 \%$ of the variance in the data.

In table 3, it reveals that the F-stat (4.675) and p-value of the explanatory variable (Beta Column) shows that firm size is significant (Sig.= 0.029). Therefore, we reject null hypotheses and uphold alternative hypothesis which state that there is a significant effect of audit firm size on return on asset of Nigerian (0.032) indicates that the hypothesis is statistically significant, hence f-sat is less than the p-value.

\section{Hypothesis Two}

Ho: Audit committee independence has no significant effect on return on equity of Nigerian banks.

Table 5: Model Summary

\begin{tabular}{|c|c|c|c|c|}
\hline Model & $\mathbf{R}$ & R Square & Adjusted R Square & Std. Error of the Estimate \\
\hline 1 & $.045^{\mathrm{a}}$ & .002 & -.004 & .40641 \\
\hline \multicolumn{5}{|c|}{ a. Predictors: (Constant), ACI } \\
\hline
\end{tabular}

Table 6: ANOVA ${ }^{\mathrm{a}}$

\begin{tabular}{|c|c|c|c|c|c|}
\hline Model & Sum of Squares & Df & Mean Square & F & Sig. \\
\hline Regression & .052 & 1 & .052 & .313 & $.576^{\mathrm{b}}$ \\
Residual Total & 25.766 & 156 & .165 & & \\
& 25.818 & 157 & & & \\
\hline
\end{tabular}

a. Dependent Variable: ROE

b. Predictors: (Constant), ACI 
Table 7: Coefficients ${ }^{\mathrm{a}}$

\begin{tabular}{|c|c|c|c|c|c|}
\hline \multirow{2}{*}{ Model } & \multicolumn{2}{|c|}{$\begin{array}{c}\text { Unstandardized } \\
\text { Coefficients }\end{array}$} & $\begin{array}{c}\text { Standardized } \\
\text { Coefficients }\end{array}$ & \multirow{2}{*}{$\mathrm{t}$} & \multirow{2}{*}{ Sig. } \\
\cline { 2 - 4 } & $\mathrm{B}$ & Std. Error & Beta & & \\
\hline (Constant) & .043 & .067 & & .654 & .514 \\
ACI & .006 & .011 & .045 & .560 & .576 \\
\hline
\end{tabular}

a. Dependent Variable: ROE

Table 5 above shows that the Model revealed the value of $\mathrm{R}^{2}=0.002$ and Adjusted $\mathrm{R}^{2}$ value is -.0034 this suggests that the model explains about $2 \%$ of the systematic variations in the dependent variable. This means that the regression explains $2 \%$ of the variance in the data.

In table 6, it reveals that the F-stat (0.313) and p-value (0.576) indicates that the hypothesis is statistically significant, hence f-sat is less than the p-value.
In table 7 , the regressed coefficient correlation result shows that an evaluation of the financial performance of the explanatory variable (Beta Column) shows that audit committee independence is significant (Sig.= 0.514). Therefore, we reject null hypotheses and uphold alternative hypothesis which state that Audit committee independence has significant effect on return on equity of Nigerian banks.

\section{Hypothesis Three}

Ho: Audit committee size has no significant effect on profit margin of Nigerian banks.

Table 8: Model Summary

\begin{tabular}{|c|c|c|c|c|}
\hline Model & R & R Square & Adjusted R Square & Std. Error of the Estimate \\
\hline 1 & $.158^{\mathrm{a}}$ & .025 & .019 & .46678 \\
\hline \multicolumn{5}{|c|}{ a. Predictors: (Constant), ACS } \\
\hline
\end{tabular}

Table 9: ANOVA ${ }^{\mathrm{a}}$

\begin{tabular}{|c|c|c|c|c|c|}
\hline Model & Sum of Squares & Df & Mean Square & F & Sig. \\
\hline Regression & .867 & 1 & .867 & 3.980 & $.048^{\mathrm{b}}$ \\
Residual Total & 33.990 & 156 & .218 & & \\
& 34.857 & 157 & & & \\
\hline
\end{tabular}

a. Dependent Variable: PM

b. Predictors: (Constant), ACS

Table 10: Coefficientsa

\begin{tabular}{|c|c|c|c|c|c|}
\hline \multirow{2}{*}{ Model } & \multicolumn{2}{|c|}{$\begin{array}{c}\text { Unstandardized } \\
\text { Coefficients }\end{array}$} & $\begin{array}{c}\text { Standardized } \\
\text { Coefficients }\end{array}$ & \multirow{2}{*}{$\mathrm{t}$} & \multirow{2}{*}{ Sig. } \\
\cline { 2 - 5 } & $\mathrm{B}$ & Std. Error & Beta & & \\
\hline (Constant) & .963 & .399 & & 2.411 & .017 \\
ACS & -.136 & .068 & -.158 & -1.995 & .048 \\
\hline
\end{tabular}

a. Dependent Variable: PM

Table 8 above shows that the Model revealed the value of $R^{2}=0.025$ and Adjusted $R^{2}$ value is .019 this suggests that the model explains about $3 \%$ of the systematic variations in the dependent variable. This means that the regression explains $3 \%$ of the variance in the data.

In table 9, it reveals that the F-stat (3.980) and p-value (0.048) indicates that the hypothesis is statistically significant, hence f-sat is less than the p-value.
In table 10, the regressed coefficient correlation result shows that an evaluation of the financial performance of the explanatory variable (Beta Column) shows that audit committee size is significant (Sig.= 0.017). Therefore, we reject null hypotheses and uphold alternative hypothesis which state that Audit committee size has significant effect on profit margin of Nigerian banks. 


\section{Discussion of Findings}

Audit quality (audit committee size, audit committee independence, and firm size) has significant effects on return on assets, return on equity and profit margin of quoted Nigerian banks.

Hypothesis one revealed that firm size has significant effects on return on assets of quoted Nigerian banks. This is in line with Egbunike and Abiahu (2017) found that audit quality has a significant effect on return on assets of Nigerian banks. Bouaziz (2012) result shows that auditor size has an important impact on the financial performance of firms in terms of return on assets and return on equity. Abu, Okpeh and Okpe (2016) findings show that foreign director is significantly and positively correlated or influenced the Performance of deposit money bank.

Hypothesis two shows that Audit committee independent has significant affect return on equity of quoted Nigerian banks; this result is in line with Temple, Ofurum and Egbe (2016) indicate that audit committee "independence has no significant effect on earnings management in quoted Nigerian banks. Farouk and Hassan (2014) results of the findings shows that auditor size and auditor independence have significant impacts on the financial performance of quoted cement firms in Nigeria. Bouaziz (2012) result shows that auditor size has an important impact on the financial performance of firms in terms of return on assets and return on equity.

Hypothesis three revealed that audit committee size has significant affects profit margin of quoted Nigerian banks. This is in line with Ziaee (2014) found that audit quality could affect the financial performance of companies. Matoke and Omwenga (2016) findings of the study indicate that the effect of audit quality on financial performance is positive and significant. Miettinen (011) shows that audit quality has both a direct effect as well as a mediated effect through audit size on financial performance.

\section{SUMMARY O FFINDINGS, CONCLUSISON AND RECOMMENDATIONS Summary of Findings}

Based on the data analyzed, the following findings were drawn:

1. Firm size has significant effects on return on assets of quoted Nigerian banks.

2. Audit committee independent has significant affect return on equity of quoted Nigerian banks.
3. Audit committee size has significant affects profit margin of quoted Nigerian banks.

\section{Conclusions}

This research work investigates the effect of audit quality on the financial performance of deposit money banks in Nigeria. The study attempted to provide empirical evidence of this effect within the Nigerian context. Findings from the study revealed that there is a significant positive effect between audit quality financial performance indices. The control variables; audit committee independence, audit reputation and firm size were found to be positively related to financial performance except audit committee size which is negative.

\section{Recommendations}

Based on the findings of the study, the researcher recommends the followings:

1. Financial institutions should make use of the services of audit firms with unquestionable track records of audit quality and reputation; hence the debate on audit quality is not a settled matter.

2. Audit firms who have a solid reputation will be less likely to employ auditors who will be willing to compromise their stand; the audit firm itself would not like to engage in any activity that will soil its name.

3. The management of the deposit money banks in Nigeria should employ the services of one of the big audit firms and where this is not possible, management should go for an audit firm whose character and integrity is beyond question.

\section{REFERENCES}

1. Abbott, L. J., Park, Y. \& Parker, S. (2000). The effects of audit committee activities and independence on corporate fraud, Managerial Finance, 26(11), 55-67.

2. Adeyemi, S. B., \& Okpala, O. (2011). The impact of audit independence on financial reporting: Evidence from Nigeria. Business and Management Review, 1(4), 9-25.

3. Amahalu. N \&Ezechukwu B., (2017). Determinants of audit quality: evidence from deposit money banks listed on Nigeria stock exchange. International journal of academic research in accounting, finance and management sciences 7(2) April 2017, pp. 117-130 E-ISSN: 2225-8329, P-ISSN: 2308-0337 (C) 2017 HRMARS www.hrmars.com 
4. Barbadillo, E., Gomez-Aguilar, N., \& Carrera, N. (2009). Does mandatory audit firm rotation enhance auditor independence? Evidence from Spain. Auditing: A Journal of Practice \& Theory, 28(1), 113-135.

5. Beasley, M.S. (1996). "Board of director composition and financial statement fraud", Accounting Review 71(4): 443-465

6. Beasley, M. S., Carcello J. V., Hermanson D. R., \& Lapides P.D. (2000). Fraudulent financial reporting: consideration of industry traits and corporate governance mechanisms", Accounting horizons 14(4): 441-454.

7. Becker, C., DeFond, M., Jiambalvo, J., \&Subramanyam, K. R. (1998). The effect of audit quality on earnings management. Contemporary accounting research, 15(1), 1-24.

8. Beasley, M. S., Carcello, J. V., Hermanson, D.R. \& Neal, T.L. (2009). The audit committee oversight process. Contemporary Accounting Research 26 (1):65-122.

9. Cameran, M., Prencipe, A., \& Trombetta, M. (2014). Mandatory Audit Firm Rotation and Audit Quality. European Accounting Review, (ahead-ofprint), 1-24.

10. Chen, C. Y., Lin, C. J., \& Lin, Y. C. (2008). Audit Partner Tenure, Audit Firm Tenure, and Discretionary Accruals: Does Long Auditor Tenure Impair Earnings

11. Corbella, S., Florio, C., Gotti, G., \& Mastrolia, S. A. (2015). Audit firm rotation, audit fees and audit quality: The experience of Italian public companies. Journal of International Accounting, Auditing and Taxation, 25, 46-66.

12. Dopuch, N., King, R. R., \& Schwartz, R. (2001). An experimental investigation of retention and rotation requirements. Journal of Accounting Research, 39(1), 93-117.

13. De Angelo, L. (1981). Auditor size and audit quality. Journal of accounting and economics, 2 (1)

14. Davis, J.H., Schoorman, F.D. \& Donaldson, L. (1997). Toward a stewardship theory of management. Academy of Management Review 22 (1):20-47.

15. Dehkordi, H. F., \& Makarem, N. (2011). The effect of size and type of auditor on audit quality.
International Research Journal of Finance and Economics, 80, 121-137.

16. Dye, R. (1993). Auditing standards, legal liability and auditor wealth. Journal of Political Economy 101 (5): 887-914.

17. Egbunike F. C. \& Abiahu M. F. (2017). Audit firm report and financial performance of money deposit banks in Nigeria.

18. Farouk, M. A., \& Hassan, S. U. (2014). Impact of Audit quality and financial performance of quoted cement firms in Nigeria. International journal

19. Ebimobowei, A., \& Keretu, O. J. (2011). Mandatory rotation of auditors on audit quality, costs and independence in South-South, Nigeria. International business management, 5(3), 166172.

20. Ernst \& Young. (2013). Point of view - our perspective on issues of concern: Q\&A on Mandatory audit firm rotation accounting and taxation, 2(2), 01-22.

21. Gerayli, M. S., Yanesari, A. M., \& Ma'atoofi, A. R. (2011). Impact of audit quality on earnings management: evidence from Iran. International research journal of finance and economics, (66).

22. Hamed S, Rohaida B, Siti Z \& Abdul R, (2015) The impact of audit quality on firm performance: evidence from Malaysia international business school, universiti teknologi Malaysia, Kuala lumpur.

23. Heil, D. (2012). The influence of the auditor on the earnings quality of their clients. (Umpublished Masters Thesis). Department of accounting, auditing and control, Erasmus University, Rotterdam.

24. Hatfield, R. C., Jackson, S. B., \& Vandervelde, S. D. (2011). The effects of prior auditor involvement and client pressure on proposed audit adjustments. Behavioral Research in $\backslash$ Accounting, 23(2), 117-130

25. International Federation of Accountants- IFAC. (2009). Rebuilding Public Confidence In Financial Reporting: An International Perspective, [Online] Available: http://web.ifac.org/publications/ifac-policyposition-papers-reports-and-commentletters/reports-1\#developments 
26. Jackson, A. B., Moldrich, M., \& Roebuck, P. (2008). Mandatory audit firm rotation and audit quality. Managerial Auditing Journal, 23(5), 420437.

27. Johnson, V. E., Khurana, I. K., \& Reynolds, J. K. (2002). Audit-Firm Tenure and the Quality of Financial Reports*. Contemporary accounting research, 19(4), 637-660.

28. Kim, H., Lee, H., \& Lee, J. E. (2015). Mandatory audit firm rotation and audit quality. Journal of Applied Business Research, 31(3), 1089.

29. Krishnan, J. \& Schauer, P. C. (2000). The differentiation of quality among auditors: Evidence from the not-for-profit sector, Auditing. A journal of practice and theory, 19, 9-25.

30. Mautz, R. K. (1964). Fundamentals of auditing. John Wiley and Sons. European Commission. (2010). Green Paper- Audit Policy: Lessons from the Crisis.

31. McMullen D.A. (1996). Audit committee performance: an investigation of the consequences associated with audit committees. Auditing: $a$ journal of practice \& theory, 15(1), 87-103

32. Miettinen, J. (2011). The role of audit quality on the relationship between auditee's agency problems and financial information quality. Paper presented at the department of accounting and finance, university of Vaasa, Finland.

33. Moradi, M., Salehi, M., \& Najari, M. (2012). A study of the effective variables on earning management: Iranian Evidence. Research journal of applied sciences, engineering and technology, 4(17), 3088-3094.

34. Mahdi, S. \& Mansoury, A. (2009). Firm size, audit regulation and fraud detection: Empirical evidence from Iran. Spring 2009 University of Zanjan, Iran, management 4 (1): 5-19.
35. Myers, J. N., Myers, L. A., \& Omer, T. C. (2003). Exploring the term of the auditor-client relationship and the quality of earnings: A case for mandatory auditor rotation. The Accounting Review, 78(3), 779-799.

36. Okolie, A. O. (2014). Accrual - based earnings management, corporate policies and managerial decisions of quoted companies in Nigeria. Research Journal of Finance and Accounting. 5 (2), $1-14$.

37. PWC (2013). Point of View Mandatory audit firm rotation - other changes would be better for investor's quality. European Accounting Review, 9(3), 419-442

38. Shafie R., Hussin W., Yusof .M \& Hussain M. (2009). Audit firm tenure and auditor reporting quality: evidence in Malaysia.

39. Soliman, M. M., \& Ragab, A. A. (2014). Audit committee effectiveness, audit quality and earnings management: an empirical study of the listed companies in Egypt. Research journal of finance and accounting, 5(2), 155-166.

40. United Kingdom House of Common Treasury Committee (2008).

41. Vanstraelen, A. (2000). Impact of renewable longterm audit mandates on audit Quality?*. Contemporary Accounting Research, 25(2), 415445.

42. Watts, R. L \& Zimmermen, J. (1986). Positive accounting theory. Engle wood cliffs: prentice hall.

43. Wild, J. (1996). The audit committee and earnings quality", Journal of accounting, auditing \& finance 11(2): 247-276.

44. Zehri，F., \& Shabou，R. (2011). audit quality, corporate governance and earnings management in the context of Tunisian Firms. Journal of administrative \& economics science, 1(1). 